\title{
SOLIDS REMOVAL IN A RECIRCULATING AQUACULTURE SYSTEM
}

\author{
El-Sayed G. Khater ${ }^{1}$, Samir A. Ali ${ }^{2}$, Adel H. Bahnasawy ${ }^{3}$, \\ Montasser A. Awad ${ }^{2}$ \\ ABSTRACT
}

The objective of this work was to investigate the efficiency of both double drain and screen filter on solids removal in recirculating aquaculture system to improve the water quality and increase the fish growth rate. A model was developed to determine the solids removal in recirculating aquaculture system. By fitting the predictions of the model to measured settleable and suspended solids, settleabe solids removal was determined that about 0.0304 to $0.0556 \mathrm{~kg} \mathrm{~m}^{-3}$ (30.40 to $55.60 \mathrm{mg} \mathrm{l}^{-1}$ ) while it was $0.039 \mathrm{~kg} \mathrm{~m}^{-3}$ (39 $\left.\mathrm{mg} \mathrm{l}^{-1}\right)$ for the theoretical approach and suspended solids removal was determined that about 0.0123 to $0.0806 \mathrm{~kg} \mathrm{~m}^{-3}$ (12.30 to $80.60 \mathrm{mg} \mathrm{l}^{-1}$ ) while it was from 0.0124 to $0.1425 \mathrm{~kg} \mathrm{~m}^{-3}$ for the theoretical approach. It was calculated that the hydrocyclone and drum filter efficiency to remove the solids from the system ranged from 27.4 to $57.79 \%$ and15.46 to $57.71 \%$ respectively. It was calculated that the hydrocyclone and drum filter efficiency to remove the solids from the system ranged from 27.4 to $57.79 \%$ and 15.46 to $57.71 \%$ respectively. The daily average of settleable and suspended solids removed by hydrocyclone and drum filter ranged from 0.33 to $6.26 \mathrm{~kg} /$ day and 0.11 to $11.43 \mathrm{~kg} /$ day, respectively. The model results were in a reasonable agreement with the experimental ones.

Keywords: Model - Settleable solids - Suspended solids - Hydrocyclone - Drum filter

\section{INTRODUCTION}

anagement and removal of solids is one key process in an
RAS. In recirculating finfish systems the main particulate
waste materials are feces, uneaten feed, decaying fish, and tank and pipes biofilm slough (Chen et al., 1993; Patterson and Watts, 2003).

1 Assistant Lecturer, 2 Associate Professor, 3 Professor

Agric. Eng. - Agric. Eng. Dept. - Faculty of Agric., Moshtohor - Benha University 
Since the adverse effects of solids on recirculating systems were recognized, research on solids removal has been recommended by many investigators (Brinker et al, 2005; Summerfelt and Penne, 2005; Davidson and Summerfelt, 2005; Steicke et al., 2007; Merino et al., 2007; Bai, 2007; Timmons and Ebeling, 2007; Sandu et al., 2008; Pfeiffer et al., 2008; Couturier et al., 2009; d'Orbcastel et al., 2009). Solids that are not removed from the RAS have numerous consequences for the fish in the system and system components. The presence of suspended solids in recirculating finfish aquaculture systems can cause damage to fish gills, increase biochemical oxygen demand, reduce biofilter nitrification, and increase ammonia in the system (Chapman $\boldsymbol{e t}$ al., 1987; Bergheim et al., 1998; Wong, 2001; Zhu and Chen, 2001). The solids found in RAS operations vary in size and settling properties and have an effect in the design and operation of the solid removal mechanisms (Merino et al., 2007). All recirculating aquaculture systems utilize processes to remove waste solids, oxidize ammonia and nitrite-N, and aerate and/or oxygenate the water. Methods or processes that improve solids removal also improve water quality, which can potentially enhance production and certain operating costs. However, selection of the best treatment system for a particular aquaculture operation is difficult, given the variety of processes available, and the lack of uniform methodology for evaluation of water treatment effectiveness and economic accounting and other practical considerations (Bai, 2007 and Timmons and Ebeling, 2007).

The effective management of solids in aquaculture is one of the major obstacles to the continued development of the aquaculture industry (Piedrahita et al., 1996) and is often considered the most critical process to manage in aquaculture systems (Summerfelt, 1996).

Feed input into the system controls the production of solids and particulate matter (feces and uneaten feed). Solids and particulate matter are the major sources of carbonaceous oxygen demand and nutrient input into the water, especially if they degrade within the system. The feed portion is not assimilated by the fish excreted as an organic waste (fecal solids) and the uneaten feed consume dissolved oxygen and generate 
total ammonia nitrogen (TAN) when broken down by bacteria within the system (Timmons and Ebeling, 2007).

The best solids removal practices remove solids from the system as soon as possible and expose the solids to least turbulence and mechanical shear (Summerfelt, 1996). Conventional solids removal processes generally remove solids larger than $100 \mu \mathrm{m}$. However, only a few processes typically used in aquaculture can remove dissolved solids or colloidal solids smaller than $20 \mu \mathrm{m}$ (Chen et al., 1994).

A variety of methods are currently used for solids removal in aquaculture operations (gravitational, filtration, or screening methods). Gravitational methods may result in the removal of particles that are less dense than water (e.g., dissolved air flotation), or the particles that are more dense than water (e.g., settling basins, centrifuges, hydrocyclones). Filtration or screening methods relies on particle size and particle surface properties for removal from the culture water. There are several commercial types of these filtration mechanisms, including drum filters, disk filers, triangle filters, etc. Other types of filtration systems are based on granular media beds (Cripps and Bergheim, 2000).

Settling basins are the most common solids removal process used in flow through aquaculture systems. Properly designed and operated, settling basins can be effective in reducing suspended solids concentrations to low levels. But they must be managed carefully to achieve high nutrient removal rates. Micro screens and settling basins have difficulty controlling fine solids below about $40 \mu \mathrm{m}$ which can create problems in high water reuse systems (Libey, 1993 and Merino et al., 2007). Stechey and Trudell (1990) evaluated the reduction in suspended solids and nutrient concentrations obtained from existing settling basins in Ontario. Variables of different types were determined: production and management, water chemistry and solids chemistry characteristics. They found that although the total suspended solids removal efficiency of existing aquaculture facilities was rather low, ranging from 15.5 to $31.7 \%$ depending on the type of settling basin used, properly designed and 
operated settling systems could achieve solids removal efficiencies approaching $90 \%$.

Modeling of solids removal processes in aquaculture processes in aquaculture systems has not received much attention in either the aquacultural or environmental engineering literature. Modeling of removal rates by settling is complicated in aquaculture water because of the variability in particle size and density of suspended solids. Thus, effective comparison of different types of solids removal systems requires the establishment of a uniform sampling and testing protocol (Delos and Malone, 1996 and Pfeiffer et al., 2008).

If flow baffles or dual-drain effluent configurations are used for continuous, hydraulic removal of settled solids (Timmons et al., 1998), then settled solids are routed to the designated effluent port and do not accumulate on benthic surfaces. Otherwise, accumulated settled solids are removed by periodic events, as specified by the maximum allowed solids accumulated and other management variables. When media is present in the water column, solid sedimentation is enhanced by interception and diffusion (Chen et al., 1994).

Rigorous quantification of solids sedimentation, whether intended or not, required consideration of (1) distributions of sizes, particle densities, and settling velocities, (2) particle interaction (e.g., flocculation), (3) water velocity profiles with a facility unit, (4) particle retention time, and (5) particle re-suspension by scouring and fish activity (James, 1984b; Tchobanoglous and Schroeder, 1985; Chen et al., 1994).

Within a recirculating aquaculture system (RAS), almost all waste products originates from the formulated diet provided to the cultured animal. The rapid buildup of this waste can lead to the decline in water quality, inducing stress upon the animal, therefore, the main objective of this work was to investigate the efficiency of both double drain and screen filter in solids removal from the recirculating aquaculture system to improve the water quality and increase the fish growth rate. 


\section{Theoretical Approach}

The effectiveness of the double drain at concentrating solids within the bottom center drain discharge can be illustrated by a steady state solids balance written over the culture tank (Tommons et al., 2002).

$$
\left\{Q . T S_{\text {in }}\right\}+\left\{T S_{P}\right\}=\left\{Q_{\text {out } 1} T S_{\text {out } 1}\right\}+\left\{Q_{\text {out } 2} \cdot T S_{\text {out } 2}\right\}
$$

Where:

$\mathrm{Q}$ is the water flow rate, $\mathrm{m}^{3} /$ day

$Q_{\text {out } 1}$ is the flow rate leaving the lateral drain, $\mathrm{m}^{3} /$ day

$\mathrm{Q}_{\text {out2 }}$ is the flow rate leaving the main drain, $\mathrm{m}^{3} /$ day

$\mathrm{TS}_{\text {in }}$ is the TS concentration entering unit, $\mathrm{kg} \mathrm{m}^{-3}$

$\mathrm{TS}_{\text {out } 1}$ is the TS concentration leaving the lateral drain, $\mathrm{kg} \mathrm{m}^{-3}$

$\mathrm{TS}_{\text {out } 2}$ is the TS concentration leaving the main drain, $\mathrm{kg} \mathrm{m}^{-3}$

$\mathrm{TS}_{\mathrm{P}}$ is the TS production rate, $\mathrm{kg}$ TS produced per day

TS resulted from feeding can be determined by using the following equation:

$$
T S_{P}=A_{T S} \cdot R_{\text {feed }} . \rho_{\text {fish }} \cdot V_{\tan k}
$$

Where:

$\mathrm{A}_{\mathrm{TS}}$ is the TS produced as a proportion of feed fed, (25\% of feed fed) as according to Hopkins and Manci (1989) and Losordo and Hobbs (2000)

$\mathrm{R}_{\text {feed }}$ is the feeding rate, $\mathrm{kg}$ feed per $\mathrm{kg}$ fish per day

$\rho_{\text {fish }}$ is the density of fish in the culture tank, $\mathrm{kg}$ fish per $\mathrm{m}^{3}$

$\mathrm{V}_{\text {tank }}$ is the volume of water contained within culture tank, $\mathrm{m}^{3}$ A simplified approach to solids sedimentation is used here, where solid removal rate by sedimentation $\left(\mathrm{TS}_{\text {out } 2}, \mathrm{~kg} \mathrm{~m}^{-3}\right)$ is:

$\mathrm{TS}_{\text {out } 2}=\mathrm{TS}_{\text {in }}($ fraction removed $)$ (exchange rate, $1 /$ day) 


$$
\mathrm{TS}_{\text {out2 }}=\mathrm{TS}_{\text {in }}\left(\mathrm{v}_{\mathrm{s}} / \mathrm{HLR}\right)(\mathrm{Q} / \mathrm{V})
$$

It could be rewritten as:-

$$
\mathrm{TS}_{\text {out2 }}=\mathrm{TS}_{\text {in }}\left(\mathrm{v}_{\mathrm{s}} / \mathrm{d}\right)
$$

Where:

$\mathrm{v}_{\mathrm{s}}$ is the particle mean settling velocity $\left(\mathrm{m} \mathrm{h}^{-1}\right)$

$\mathrm{d}$ is the water depth $(\mathrm{m})$

HLR is the hydraulic loading rate $\left(\mathrm{m}^{3} \mathrm{~m}^{-2} \mathrm{~h}^{-1}\right)$

This derivation represents solid sedimentation in terms of first order, exponential decay kinetics, a simplification that has been used exponential decay kinetics, a simplification that has been used by others (Fritz et al., 1979; Fritz, 1985; James, 1984; Piedrahita and Giovannini, 1989). The sedimentation term represents one term in the differential equation for $\mathrm{TS}_{\mathrm{in}}$, with additional sources and sink added as needed. If the water body is stratified, then solids settle from the top layer to the bottom layer and from the bottom layer and from the bottom layer to the bottom surface of the facility unit. Any upward vertical mixing of solids is considered by the use of reduced settling velocities. Typical particle settling velocity used in model is given by (Chesness $\boldsymbol{e t}$ al., 1975; Chen et al., 1994) mention that solids of fish in basin designed for sedimentation 0.83 to $5 \mathrm{~m} \mathrm{~h}^{-1}$ for 65 to $90 \%$ of total particulate solids.

\section{Materials and Methods}

The experiment was carried out at Agricultural Engineering Department, Faculty of Agriculture, Moshtohor, Benha University. During the period of March to July, 2011.

\subsection{Materials}

\subsubsection{System Description:}

Figure (1) illustrates the experimental setup. It shows the recirculating aquaculture system which consists of fish tank, hydrocyclone, screen filter, biological filter and aeration tank. 


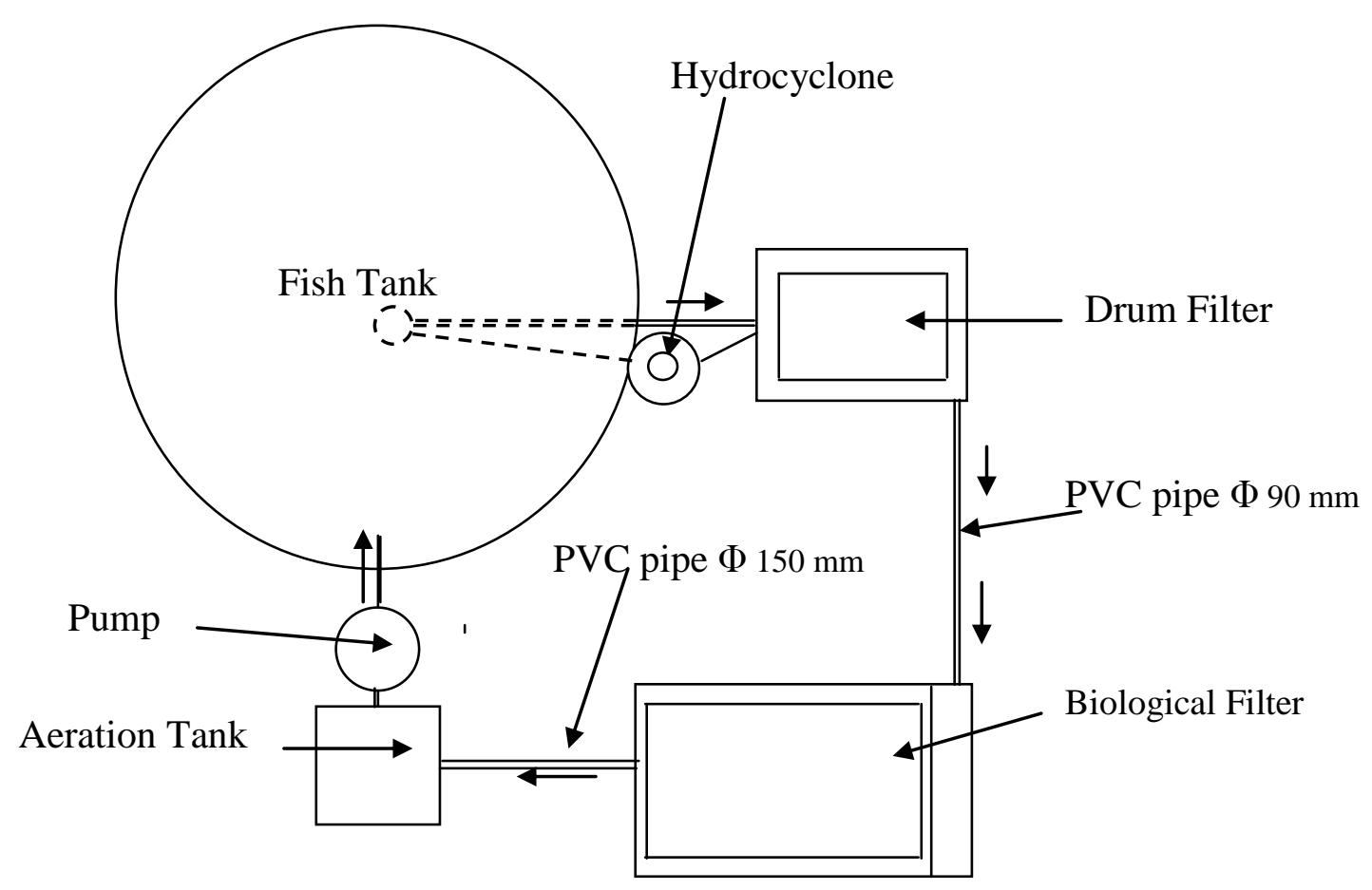

Figure (1): Recirculating aquaculture system.

Fish tank is a circular in shape and made from fiberglass has to openings for both settleable and suspended solids. Its volume is $7 \mathrm{~m}^{3}$ and has a diameter of $3 \mathrm{~m}$. The first opening allows for $1-10 \%$ of the total flow, the second opening allows for $90-99 \%$ of the total flow.

The hydrocyclone is used to remove the settleable solids which made from stainless steel and has inlet diameter of $30 \mathrm{~mm}$, overflow diameter of $50 \mathrm{~mm}$, height of $350 \mathrm{~mm}$, top diameter of $335 \mathrm{~mm}$, underflow of 50 $\mathrm{mm}$ and cone angle of $68^{\circ}$.

The drum screen filter used in this system which has dimensions were 0.7 $\mathrm{m}$ in diameter and $0.8 \mathrm{~m}$ long. The filter was made from stainless steel at private company for steel industry. The fine mesh silk 60 micron was used a media of screening. The filter was driven by one motor of $0.5 \mathrm{~kW}$ power and $1500 \mathrm{rpm}$ and a gearbox was used to reduce the rotation speed 500 times to give the recommended rotating speed ( $3 \mathrm{rpm}$ ). 
Rotating Biological Contactor (RBC) used in this system, has $1.2 \mathrm{~m}$ in diameter and $1.5 \mathrm{~m}$ long. The filter was made from stainless steel. Used plastic sheets were used as a media. The filter was driven by one motor of $1.5 \mathrm{~kW}$ power and $1500 \mathrm{rpm}$ and a gearbox to reduce the speed 500 times to give the recommended rotating speed $(3 \mathrm{rpm})$.

Air-contact aeration system was used to transfer all gases present in atmospheric air into water. This system can only increase dissolved oxygen concentrations to saturation, and the efficiency of oxygen transfer declines as the dissolved oxygen concentration in water increase (Boyd, 1982). The air was pumped to the aeration tank by an air blower, under various pressures through leaky pipes of $16 \mathrm{~mm}$ in diameter of different lengths. The tank has a dimensions of $1 \times 1 \times 1 \mathrm{~m}^{3}$ and was totally filled with water.

\subsection{Methods}

Tilapia nilotica fingerlings, which were used in the experiment, were brought from the General Authority for Fish Resources Development of A.R.E. in El-Knater El-Khiria, Kalubia, Eygpt. The fish was weighed every week and the flow rate was adjusted according to the growth rate. The weekly fish weight was used to adjust both of water flow rate and length of leaky pipe and air pressure of the aerator.

The daily feed rates at different fish sizes were applied according to Rakocy (1989) and the feed pellet diameter was prepared according to Jauncey and Ross (1982). Feeding was stopped during weighing process.

Water samples were collected daily from four locations, at the inlet and the outlet of the screen filter for measuring suspended solids, and at the inlet and the outlet of the hydrocyclone for measuring settleable solids according to APHA (1998). The samples were stored in refrigeration for analysis.

Settleable solids removal and hydrocyclone efficiency were calculated as follows: 


$$
\begin{gathered}
S S R_{h}=\frac{S S_{\text {hin }}-S S_{\text {hout }}}{1000} \\
\eta_{h}=\frac{\left(S S_{h_{\text {in }}}-S S_{h_{\text {out }}}\right)}{S S_{\text {hin }}} \times 100
\end{gathered}
$$

Where:

$\mathrm{SSR}_{\mathrm{h}}$ is the settleable solids removed, $\mathrm{kg} \mathrm{m}^{-3}$

$\mathrm{SS}_{\mathrm{h}}$ in is the settleable solids at the inlet the hydrocyclone, $\mathrm{mg}^{-1}$

$\mathrm{SS}_{\mathrm{h} \text { out }}$ is the settleable solids at the outlet the hydrocyclone, $\mathrm{mg}^{-1}$

$\eta_{\mathrm{h}}$ is the removal efficiency for settleable solids (\%)

Suspended solids removal and screen filter efficiency were calculated as follows:

$$
\begin{array}{r}
S S R_{f}=\frac{S S_{f \text { in }}-S S_{f \text { out }}}{1000} \\
\eta_{f}=\frac{\left(S S_{f_{\text {in }}}-S S_{f_{\text {out }}}\right)}{S S_{f_{\text {in }}}} \times 100
\end{array}
$$

Where

$\mathrm{SSR}_{\mathrm{f}}$ is the suspended solids removed, $\mathrm{kg} \mathrm{m}^{-3}$

$\mathrm{SS}_{\mathrm{f} \text { in }}$ is the suspended solids at the inlet the screen filter, $\mathrm{mg}^{-1}$ $\mathrm{SS}_{\mathrm{f} \text { out }}$ is the suspended solids at the outlet the screen filter, $\mathrm{mg}^{-1}$ $\eta_{\mathrm{f}}$ is the screen filter efficiency for suspended solids (\%)

\section{RESULTS AND DISCUSSION}

\subsection{Settleable Solids}

There are two levels of solids that to be removed from the recirculating aquaculture system (RAS), one is the settleable solids which is more dependent on the gravity rather than centrifugal force, while the second type is the suspended solids which is dependent on the centrifugal force. The hydrocyclone was used to remove the settleable solids from the 
(RAS). The data was recorded daily. Fig (2) shows the predicted and measured settleable solids removal from the recirculating aquaculture system (RAS). It indicates that the average settleable solids removal from the system was $0.0429 \pm 0.0127 \mathrm{~kg} \mathrm{~m}^{-3}\left(42.90 \pm 12.70 \mathrm{mg} \mathrm{l}^{-1}\right)$ and it could be seen that the average daily solids removed from the system ranged from 0.33 to $6.62 \mathrm{~kg} /$ day experimentally while it was estimated to be from 0.34 to $4.41 \mathrm{~kg} /$ day theoretically fig (3).

The variations between the predicted and the measured are shown in fig (2) which shows that the predicted and the measured are in a reasonable agreement. The best fit for the relationship between the predicted and the measured values is in the following equation:

$S S R_{h p}=0.039-9.6 \times 10^{-23} S_{S R} \quad \mathrm{R}^{2}=0.999$

Where:

$\mathrm{SSR}_{\mathrm{hp}}$ is the predicted settleable solids removal by hydrocyclone, $\mathrm{kg} \mathrm{m}^{-3}$

$\mathrm{SSR}_{\mathrm{hm}}$ is the measured settleable solids removal by hydrocyclone, $\mathrm{kg} \mathrm{m}^{-3}$

\subsection{Suspended Solids}

Fig (4) shows the predicted and the measured suspended solids removal from the recirculating aquaculture system (RAS).

It could be seen that the suspended solids removed by the system increased with growth period, where it was about $0.0123 \mathrm{~kg} \mathrm{~m}^{-3}(12.30$ $\mathrm{mg} \mathrm{l}^{-1}$ ) at the beginning and increased rapidly to reach $0.0806 \mathrm{~kg} \mathrm{~m}^{-3}$ $\left(80.60 \mathrm{mg} \mathrm{l}^{-1}\right.$ ) after 3 months. Also, the results show that the average daily solids removed from the system ranged from 0.11 to $11.34 \mathrm{~kg} / \mathrm{day}$ experimentally while it was from 0.11 to $15.70 \mathrm{~kg} /$ day for the theoretical approach fig (5).

The variations between the predicted and the measured are shown in fig (4). It shows the predicted and measured are in a reasonable agreement. The best fit for the relationship between the predicted and measured values was as follows:

$$
S S R_{f p}=1.59 S S R_{f m}-0.015 \quad \mathrm{R}^{2}=0.915
$$

Where:

$\mathrm{SSR}_{\mathrm{fp}}$ is the predicted suspended solids removal by filter, $\mathrm{kg} \mathrm{m}^{-3}$ $\mathrm{SSR}_{\mathrm{fm}}$ is the measured suspended solids removal by filter, $\mathrm{kg} \mathrm{m}^{-3}$ 
These results are in agreement with Steicke et al. (2007) whose found that the suspended solids removed from 0.0104 to $0.0400 \mathrm{~kg} \mathrm{~m}^{-3}$ (10.40 to $40.00 \mathrm{mg} \mathrm{l}^{-1}$ ).

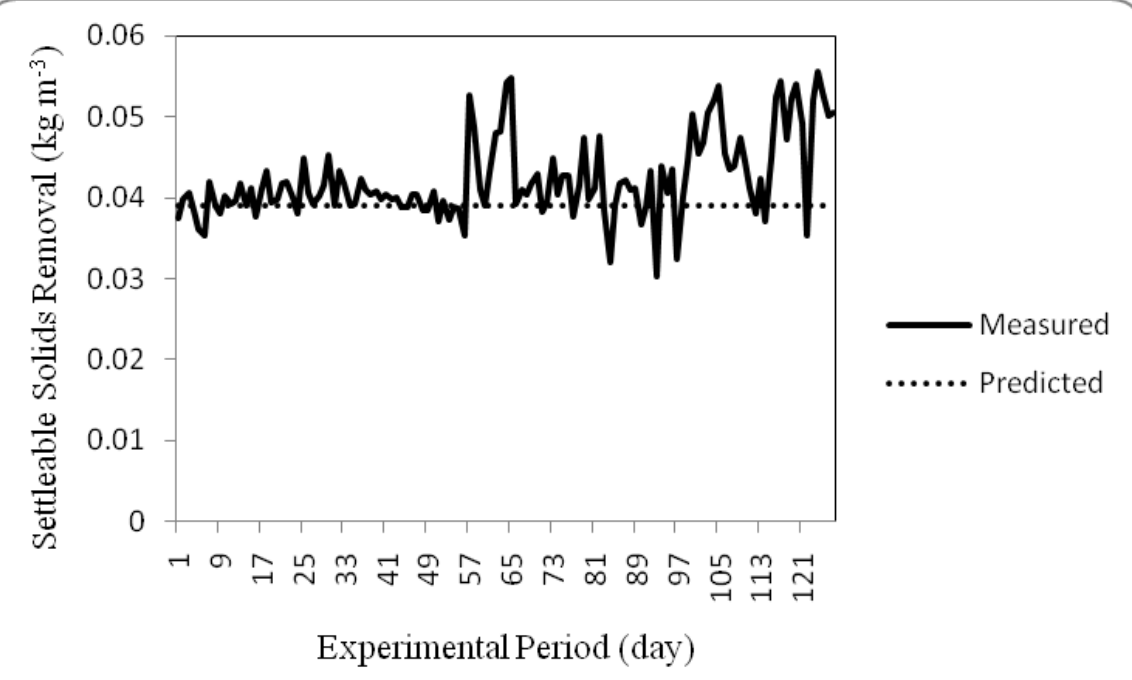

Fig. (2) The predicted and the measured settleable solids removed from the system (RAS).

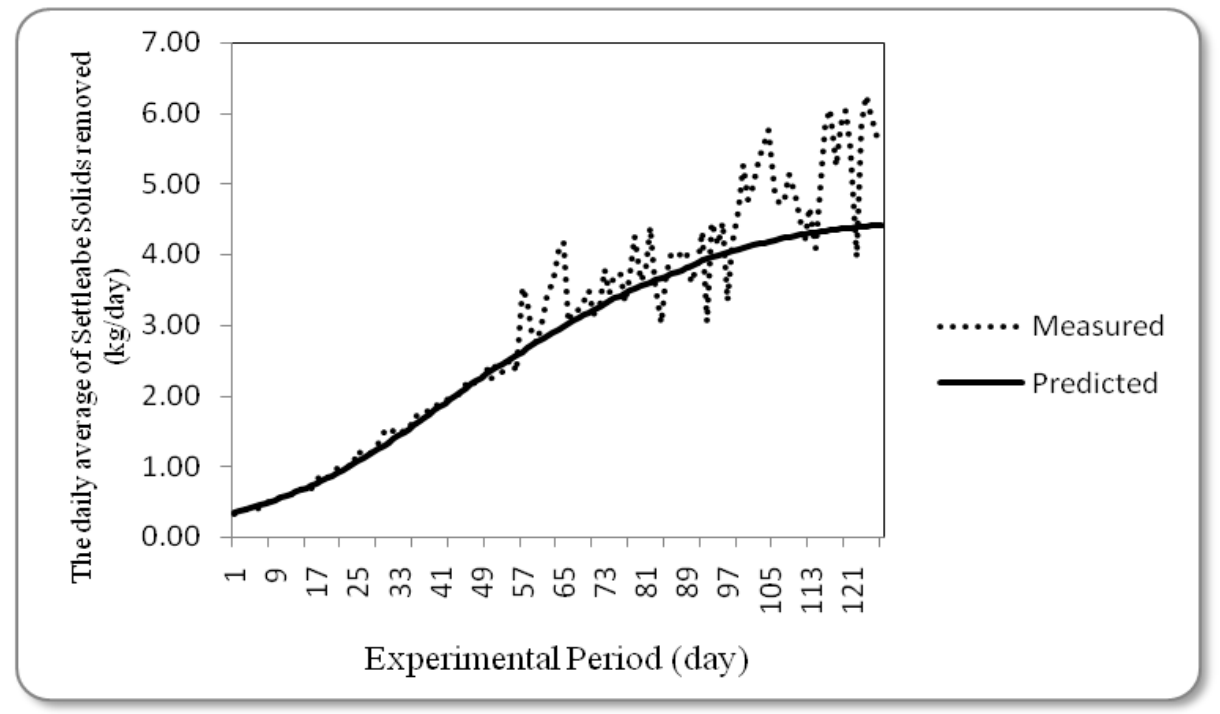

Fig. (3) The daily average of settleable solids removed by hydrocyclone (kg/day) 


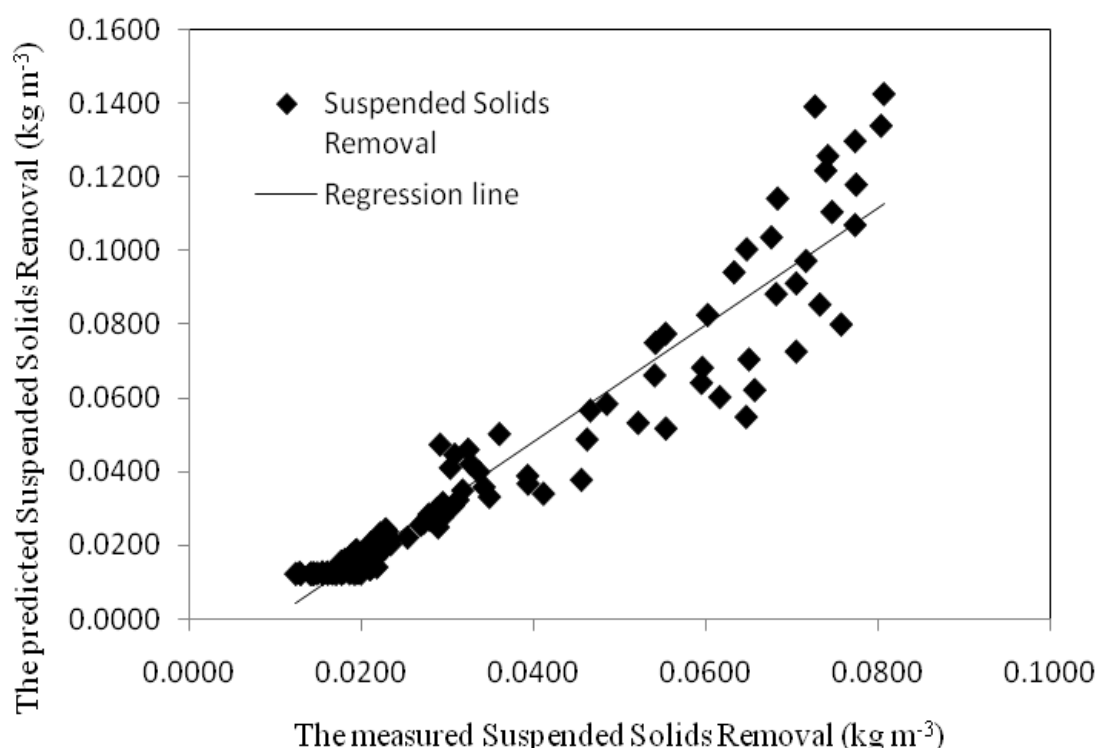

Fig. (4) The predicted and the measured suspended solids removal from the system (RAS)

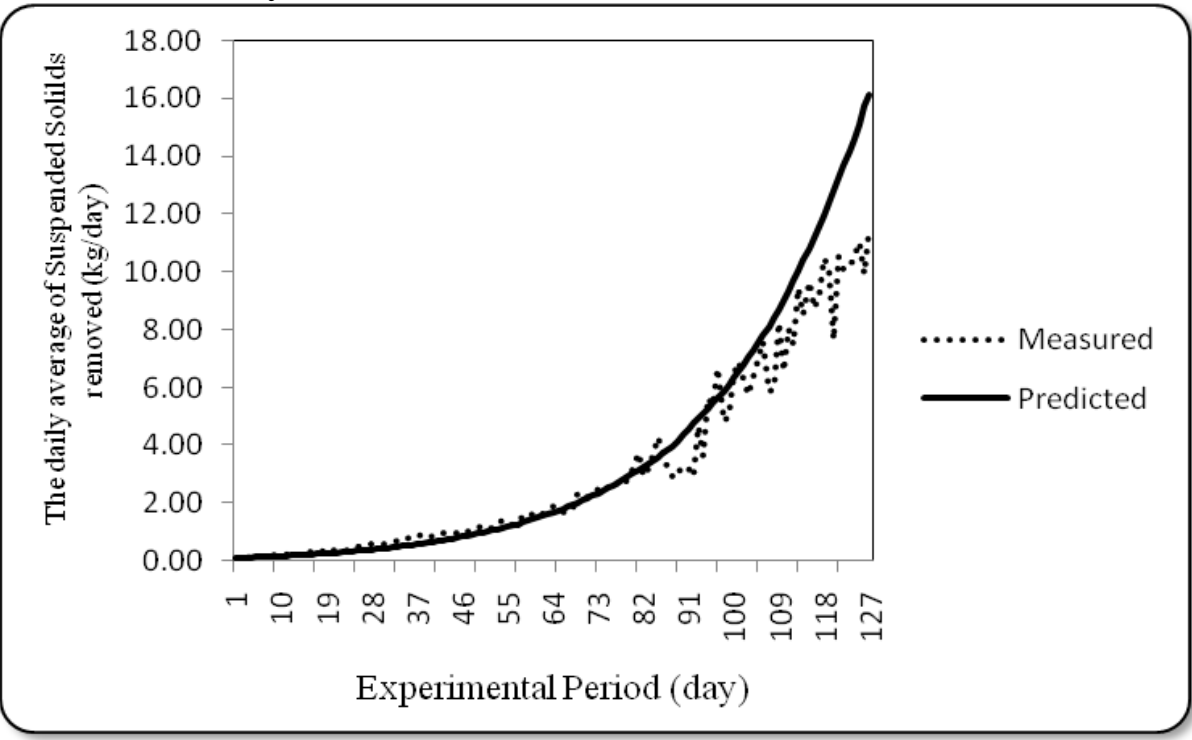

Fig. (5) The daily average of suspended solids removed by drum filter (kg/day) 


\subsection{The efficiency in removing solids}

\section{Hydrocyclone efficiency in removing settleable solids:}

Hydrocyclone efficiency in removing settleable solids was determined by measuring the settleable solids concentration in the water entering the hydrocyclone and the settleable concentration in the water leaving the it. The data represented in Fig. (6) shows that the efficiency of the hydrocyclone for settleable solids removal from the system ranged from 27.4 to $57.79 \%$. These results are in agreement with those obtained by Twarowska et al. (1997).

\section{The drum filter efficiency:}

The efficiency of the drum filter was determined by measuring the suspended solids concentration in the water entering the drum and the suspended concentration in the water leaving the drum. Since the drum was continuously rotated and the backwash water was always on, this provided a convenient means of measuring drum efficiency. The data presented in fig. (6) shows the efficiency of the drum filter for suspended solids removal from the system which ranged from 15.46 to $57.71 \%$. These results are in agreement with d'Orbcastel et al. (2009) whose found that the suspended solids efficiency of $40 \pm 18.5 \%$.

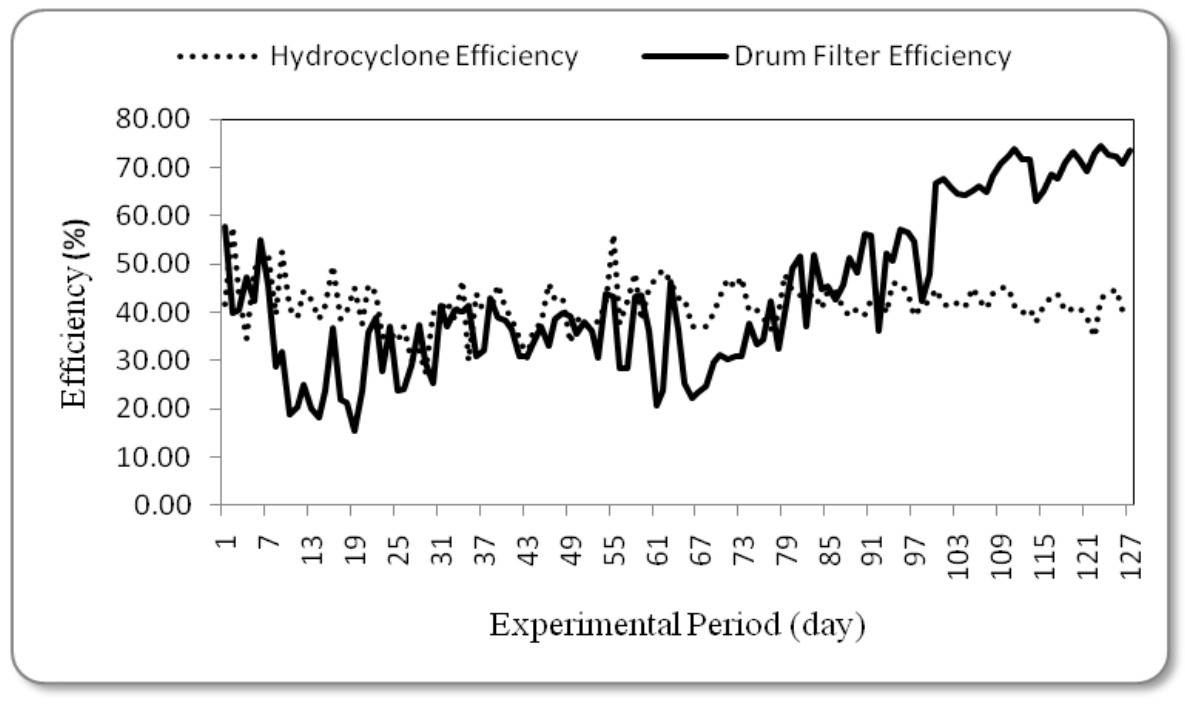

Fig. (6) The efficiency of the removal settleable and suspended solids (\%) 


\section{CONCLUSIONS}

An experiment to investigate the efficiency of both hydrocyclone and screen filter in removing both seatleable and suspended solids was carried out successively. Statistics model was developed to predicted the settleable and suspended solids removed from the recirculating aquaculture system (RAS). The results indicated that the settleable and suspended solids removed by the recirculating aquaculture system (RAS) ranged from 0.0304 to $0.0556 \mathrm{~kg} \mathrm{~m}^{-3}$ and 0.0123 to $0.0806 \mathrm{~kg} \mathrm{~m}^{-3}$, respectively. The efficiency of the hydrocyclone and the drum filter to removed settleable and suspended solids ranged from 27.4 to $57.79 \%$ and 15.46 to $57.71 \%$, respectively. The daily average of settleable and suspended solids removed by hydrocyclone and drum filter ranged from 0.33 to $6.26 \mathrm{~kg} / \mathrm{day}$ and 0.11 to $11.43 \mathrm{~kg} / \mathrm{day}$, respectively. The model results were in a reasonable agreement with the experimental ones.

\section{REFERENCES}

APHA (1998). Standard Methods for Examination of Water and Wastewater, American Public Health Association, American Water Works Association, Water Pollution Control Federation Washington, DC.

Bai, C. (2007). President's column. World Aquaculture Magazine, 38 (4): 3 .

Bergheim, A., S. Cripps and H. Litved (1998). A system for the treatment of sludge from land-based fish farms. Aquatic Living Resources, 11: 279-287.

Boyd, C. E. (1982). Water quality in warm water in ponds. Auburn university, Agricultural Experiment station, Auburn, Alabama, 35 pp.

Brinkera A., H. G. SchrÖderc, and R. RÖscha (2005). A highresolution technique to size suspended solids in flow-through fish farms. Aquacultural Engineering, 32 (4): 325-341. 
Chapman, P. E., J. D. Popham, J. Griffin and J. Michaelson (1987). Differentiation of physical from chemical toxicity in solid waste fish bioassay. Water, Air, and Soil Pollution 33: 295-309.

Chen, S., D. E. Coffin and R. F. Malone (1994). Suspended solids control in recirculating aquaculture systems. In: Timmons, M.B., Losordo, T.M. (Eds.), Aquaculture Water Reuse Systems: Engineering Design and Management. Elsevier, Amsterdam, pp. $61-100$.

Chen, S., M. B. Timmons, D .J. Aneshansley, and J. J. Bisogni (1993). Suspended solids characteristics from recirculating aquacultural systems and design implications. Aquaculture, 112: 143-155

Chesness, J. L., W. H. Poole and T. K. Hill (1975). Settline basin design for raceway fish production systems. Trans. of the ASAE, paper no. $74-5005$.

Couturier, M., T. Trofimencoff, J. U. Buil and J. Conroy (2009). Solids removal at a recirculating salmon-smolt farm. Aquacultural Engineering, 41 (3): 71-77.

Cripps, S. and A. Bergheim (2000). Solids management and removal for intensive land-based aquaculture production systems. Aquacultural Engineering, $22(1-2): 33$ - 56.

d'Orbcastel, R. E., J. P. Blancheton and A. Belaud (2009). Water quality and rainbow trout performance in a Danish Model Farm recirculating system: Comparison with a flow through system. Aquacultural Engineering, 40 (2): 135-143.

Davidson, J. and S. T. Summerfelt (2005). Solids removal from a coldwater recirculating system-comparison of a swirl separator and a radial-flow settler. Aquacultural Engineering 33: 47-61.

Delos-Reyes, A. A. and R. F. Malone (1996). Design and evaluation of a commercial-scale, paddle-washed floating bead filter. In Successes and Failures in Commercial Recirculating Aquaculture, 
editors Northeast Regional Agricultural Engineering Service (NRAES). NRAES-98, 1: 183 - 195.

Fritz, J. J. (1985). Mathematical models for waste stabilization ponds. In: S. E. Jorgenson and M. J. Gromiec (eds.), Mathematical Models in Biological Waste Water Treatment, Elsevier, Amsterdam. Pp. $169-241$.

Fritz, J. J., A. C. Middleton and D. D. Meredith (1979). Dynamic process modeling for wastewater stabilization ponds. Jour. Water Poll. Control Fed., 51: 2724 - 2743.

Hopkins, T. A. and W. E. Manci (1989). Feed conversion, waste and sustainable aquaculture, the fate of feed. Aquaculture Magazine, 15 (2): $32-36$.

James, A. (1984). An Introduction to water quality modeling. Wiley Interscience, New York. 234 p.

James, A. (1984b). Modelling of sedimentation. In: A. James (ed.), An Introduction to Water Quality Modelling. Wiley Interscince, New York, pp. $169-181$.

Jauncey, K. and B. Ross (1982). A guide to tilapia feeds and feeding. Institute of aquaculture, university of sterling, Scotland. $111 \mathrm{pp}$.

Libey, G. S. (1993). Evaluation of a drum filter for removal of solids from recirculating aquaculture system. In: Techniques for Modern Aquaculturre, Wang, J. K. (editors), Saint Joseph, Michigan, ASAE.

Losordo, T. M. and A. O. Hobbs (2000). The design and operational characteristics of the CP\&L/EPRI fish barn: a demonstration of recirculating aquaculture technology. Aquacultural Engineering, 22: 3-16.

Merino, G. E., R. H. Piedrahita and D. E. Conklin (2007). Settling characteristics of solids settled in a recirculating system for 
California halibut (Paralichthys californicus) culture. Aquacultural Engineering, 37, $79-88$.

Patterson, R. and K. Watts (2003). Micro-particles in recirculating aquaculture systems: microscopic examination of particles. Aquacultural Engineering, 28 (2): 115-130.

Pfeiffer, J. T., A. Osborn and M. Davis (2008). Particle sieve analysis for determining solids removal efficiency of water treatment components in a recirculating aquaculture system. Aquacultural Engineering, 39 (1): $24-29$.

Piedrahita, R. H. and P. Giovannini (1989). Diel aquaculture models: listings, descriptions and operating instructions. Technical Committee Meeting 1989, PD/A CRSP, Davis, CA, 50 pp.

Piedrahita, R. H., W. H. Zachritz, U. K. Fitzsimmons and C. Brckway (1996). Evaluation and improvement of solids removal systems for aquaculture. In Successes and Failures in Commercial Recirculating Aquaculture, editors Northeast Regional Agricultural Engineering Service (NRAES). NRAES-98, 1: 141 - 150.

Rakocy, J. E. (1989). Tank culture of tilapia. In the biology and culture of tilapia, ed. R. S. V. Pullin \& R. H. Lowe-McConell-ICLARM conference proceedings 7 . International center for living aquatic resources management, manila, the Philippines.

Sandu, S., B. Brazil and E. Hallerman (2008). Efficacy of a pilot-scale wastewater treatment plant upon a commercial aquaculture effluent I. Solids and carbonaceous compounds. Aquacultural Engineering, 39 (2): 78-90.

Stechey, D. and Y. Trudell (1990). Aquaculture wastewater treatment: Wastewater characterization and development of appropriate treatment technologies for the Ontario trout production industry. Reported prepard for Environmental Services. Water Resources, Ministry of the Environment. Queen's Printer for Ontario. 
Steicke, C., V. Jegatheesan and C. Zeng (2007). Mechanical mode floating medium filters for recirculating system in aquaculture for higher solids retention and lower freshwater usage. Bioresource Technology, 98 (17): 3375 - 3383.

Summerfelt, R. C. and C. R. Penne (2005). Solids removal in a recirculating aquaculture system where the majority of flow bypasses the microscreen filter. Aquacultural Engineering, 33 (2): $214-224$.

Summerfelt, S. T. (1996). Engineering design of modular and scaleable recirculating systems containing circular tank, microscreen filters, fluidized-sand biofilters, cascade aerators, and low head or u-tube oxygenators. In Successes and Failures in Commercial Recirculating Aquaculture, editors Northeast Regional Agricultural Engineering Service (NRAES). NRAES-98, 1: 217 - 244.

Tchobanoglous, G. and E. D. Schroeder (1985). Water quality: characteristics, modeling, modification. Addison-Wesley, Reading MA. 768 p.

Timmons, M. B. and J. M. Ebeling (2007). Recirculating aquaculture. Cayuga Aqua Ventures, Ithaca, NY.

Timmons, M. B., J. M. Ebeling, F. W. Wheaton, S. T. Summerfelt and B. J. Vinci (2002). Recirculating aquaculture systems. $2^{\text {nd }}$ Edition. NRAC publication No. 01-002. Printing, Robert E. Kvieger Publishing Company. Malabar, Florida.

Timmons, M. B., S. T. Summerfelt and B. J. Vinci (1998). Review of circular tank technology and management. Aquacultural Engineering, 18: $51-69$.

Twarowska, J. G., P. W. Westerman and T.M. Losordo (1997). Water treatment and waste characterization evaluation of an intensive recirculating fish production system. Aquacultural Engineering, 16: $133-147$. 
Wong, K. (2001). Enhanced solids removal for aquaculture raceways. Doctoral Dissertation. Biological and Agricultural Engineering, University of California, Davis, CA.

Zhu, S. and C. Chen (2001). Effects of organic carbon on nitrification rate in fixed film biofilters. Aquacultural Engineering, 25 (1): 1-13.

الملخص العربيى

إزالة المخلفات الصلبة فى نظام إعادة تدوير المياه

فى الزراعة المائية

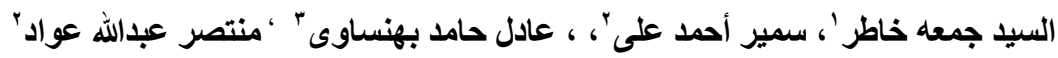

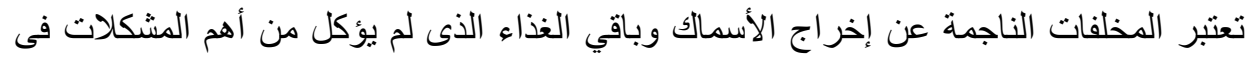

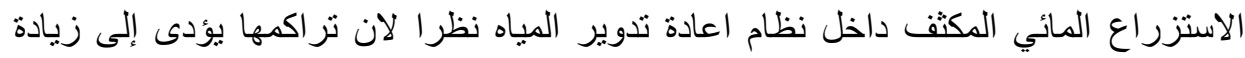

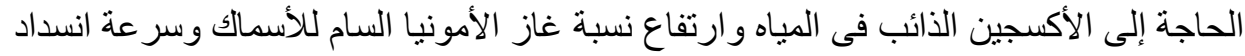

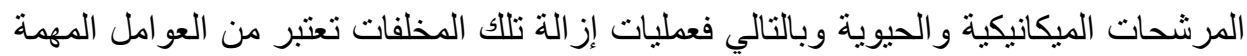

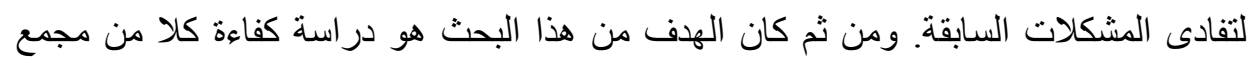

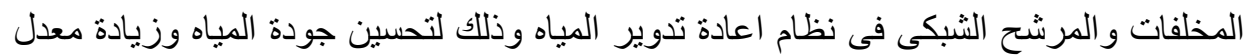

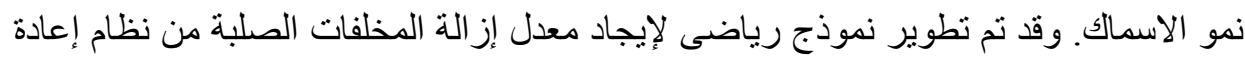
تدوير المياه، وكانت أهم النتائج كما يلى نئ:

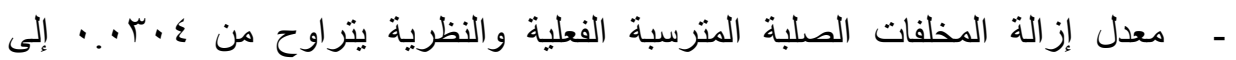

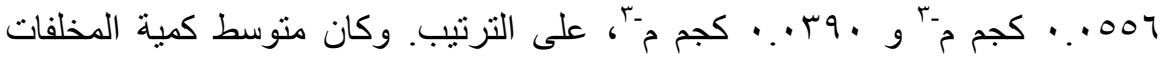

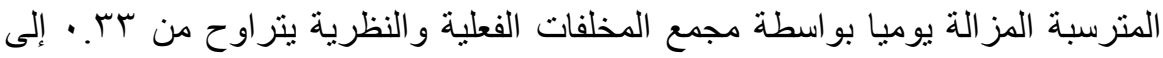

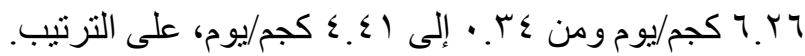

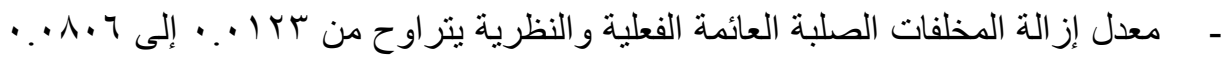

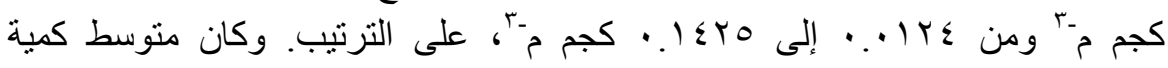

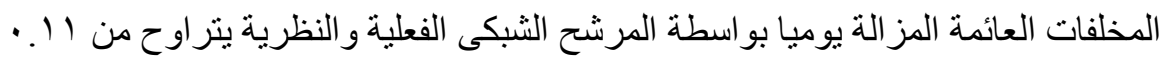

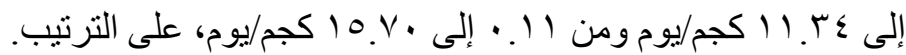

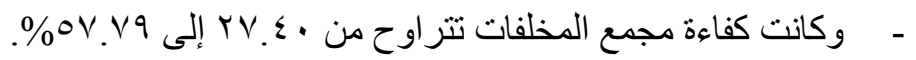

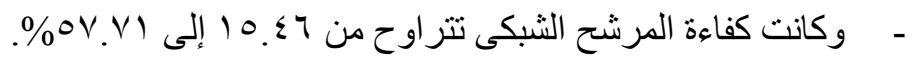

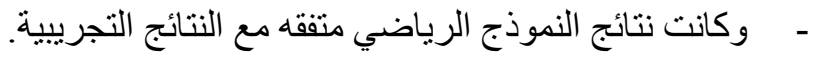

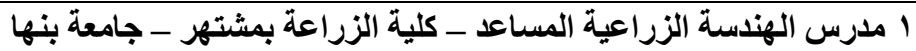

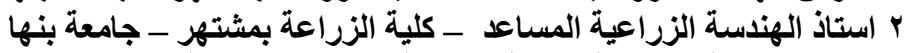
r استاذ الهندة الزراعية ـ كلية الزراعة بمثتهر - جامعة بنها 